\title{
Symbiotic nitrogen fixation and interspecific transfer by Caragana microphylla in a temperate grassland with ${ }^{15} \mathrm{~N}$ dilution technique
}

\author{
Shengnan Ouyang ${ }^{\mathrm{a}}$, Yuqiang Tian ${ }^{\mathrm{a}, *}$, Qianyuan Liu ${ }^{\mathrm{b}}$, Li Zhang ${ }^{\mathrm{b}}$, Yuan Sun ${ }^{\mathrm{c}}$, \\ Xingliang $\mathrm{Xu}^{\mathrm{b}, *}$, Yinghui Liu ${ }^{\mathrm{d}}$ \\ ${ }^{a}$ Center for Human-Environment System Sustainability (CHESS), State Key Laboratory of Earth Surface Processes and Resource Ecology, Beijing Normal \\ University, Haidian District, Beijing 100875, China \\ ${ }^{\mathrm{b}}$ Key Laboratory of Ecosystem Network Observation and Modeling, Institute of Geographic Sciences and Natural Resources Research, Chinese Academy of \\ Sciences, Beijing 100101, China \\ ${ }^{\mathrm{c}}$ School of Life Sciences, Yunnan University, NO. 2, Cuihu, Kunming 650091, China \\ d College of Resources Science and Technology, Beijing Normal University, Beijing 100875, China
}

\section{A R T I C L E I N F O}

\section{Article history:}

Received 31 July 2015

Received in revised form 8 February 2016

Accepted 10 August 2016

Available online 1 September 2016

\section{Keywords:}

Caragana microphylla

Nitrogen fixation

Nitrogen transfer

Temperate grassland

${ }^{15} \mathrm{~N}$ dilution technique

\begin{abstract}
A B S T R A C T
Quantification of symbiotic nitrogen $(\mathrm{N})$ fixation by legume and its $\mathrm{N}$ transfer to the neighboring plants is an important prerequisite to understand the $\mathrm{N}$ cycling in the $\mathrm{N}$-limited grasslands. The objective of this study is to explore the symbiotic $\mathrm{N}_{2}$-fixation by a legume shrub (Caragana microphylla) and its $\mathrm{N}$ transfer to coexisting non-legumes with the ${ }^{15} \mathrm{~N}$ dilution technique. A paired experimental design (legume vs. non-legume quadrats) was used. A small amount $\left(0.03 \mathrm{~g} \mathrm{~N} \mathrm{~m}^{-2}\right)$ of ${ }^{15} \mathrm{~N}$-labeled $\mathrm{KNO}_{3}\left(99.5 \%{ }^{15} \mathrm{~N}\right.$ enrichment) was evenly distributed in these paired labeled quadrats, with only water additions as the control. One month after the ${ }^{15} \mathrm{~N}$ addition, aboveground parts of $C$. microphylla and four non-legumes of reference plants (i.e. Cleistogenes squarrosa, Artemisia frigida, Artemisia capillaris and Leymus chinensis) in both labeled and controlled quadrats were harvested. Symbiotic $\mathrm{N}_{2}$-fixation and transfer to non-legumes were estimated based on the aboveground biomass and its ${ }^{15} \mathrm{~N}$ in these plant species. The $\mathrm{N}$ derived from the atmosphere (\%Ndfa) of C. microphylla was estimated to range from 84 to $95 \%$. According to the aboveground biomass of $C$. microphylla, symbiotic $\mathrm{N}_{2}$-fixation was estimated to be $4.3 \mathrm{~g} \mathrm{~m}^{-2} \mathrm{yr}^{-1}$ in the mixed C. microphylla community in the temperate grassland of northern China. The amount of $\mathrm{N}$ transfer from $C$. microphylla to their coexisting plants varied with plant species. About half of above $\mathrm{N}$ in $C$. squarrosa derived from C. microphylla, while L. chinensis showed almost no N derived from C. microphylla. Both A. frigida and A. capillaris showed about $36 \%$ and $37 \%$ of $\mathrm{N}$ derived from C. microphylla, respectively. Totally, about $17 \%$ of $\mathrm{N}$ fixed in the aboveground part of $C$. microphylla was transferred to its associated species. Considering the amount of $\mathrm{N}$ fixed and transferred by $\mathrm{C}$. microphylla, we conclude that $C$. microphylla plays an important role in the $\mathrm{N}$ cycling of temperate grasslands in northern China.
\end{abstract}

(c) 2016 Elsevier B.V. All rights reserved.

\section{Introduction}

Nitrogen $(\mathrm{N})$ is an important nutrient limiting plant growth in most terrestrial ecosystems (Vitousek and Howarth, 1991; Lebauer and Treseder, 2008). Legume-rhizobium symbiosis can provide about $65 \%$ bioavailable $\mathrm{N}$ in the biosphere (Peoples et al., 1995). Therefore, biological $\mathrm{N}_{2}$-fixation by legumes is much important for maintenance of ecosystem functions and restoration of degraded grasslands (Murray and Clements, 1998; Cusack et al., 2009).

\footnotetext{
* Corresponding authors.

E-mail addresses: tyq@bnu.edu.cn (Y. Tian), xuxingl@hotmail.com (X. Xu).
}

In addition to $\mathrm{N}$ fixation, legumes can also transfer a part of $\mathrm{N}$ they fixed to coexisting non-legumes (Murray et al., 2008; Issah et al., 2015). Nitrogen transfer mainly occurs via three pathways: i.e. mycorrhizal networks between legume and non-legume roots (Jalonen et al., 2009), direct uptake of $\mathrm{N}$ compounds exuded by legume roots (Ta et al., 1986; Jiang and Zhai 2000), or direct uptake of mineralized $\mathrm{N}$ derived from dead legume nodules and senescing root materials (Butler et al., 1959; Pirhofer-Walzl et al., 2012). Using the ${ }^{15} \mathrm{~N}$ isotope techniques (Sierra and Daudin, 2010; Carlsson and Huss-Danell, 2014; Chalk et al., 2014), some studies showed that up to $30 \%$ of the $\mathrm{N}$ fixed by legumes can be transferred to non-legumes (Hauggaard-Nielsen et al., 2001; Peoples et al., 2002; Herridge et al., 2008). This indicates that in the N-limited 
soils where the legumes grow, coexisting non-legume species can benefit from symbiotic $\mathrm{N}_{2}$-fixation (Høgh-Jensen and Schjoerring, 2000; Sierra and Nygren, 2006).

Additionally, legumes can conserve soil and water, provide a variety of products and improve the soil fertility in terrestrial ecosystems (Li et al., 2002; Niu and Jiang, 2004; Li et al., 2010). Caragana microphylla, a legume shrub, widely distributes in temperate grasslands of northern China. About 5 million $\mathrm{hm}^{2}$ is covered by C. microphylla, corresponding to $6.5 \%$ of the total grassland area of China (Zhou, 1990). Due to overgrazing in recent decades, a large area of temperate grasslands in northern China are experiencing degradation (Gao et al., 2004; Niu and Jiang, 2004; Yan et al., 2014). Many studies have observed that $C$. microphylla often occurs in degraded grasslands (Xiong et al., 2003; Xiong and Han, 2006), and thrives in low $\mathrm{N}$ fertility soils (Pollock and Svendsen, 2008; Zhang et al., 2011) because they can utilize $\mathrm{N}$ from the atmosphere through associated rhizobium (Moukoumi et al., 2012). In these grasslands, C. microphylla can form a "fertility island" due to its biological $\mathrm{N}$ fixation and increased litter inputs (Schlesinger and Pilmanis, 1998; Chu et al., 2005; Xiong and Han, 2006). It has a potential to transfer its fixed $\mathrm{N}$ to accompanied plants and improve their $\mathrm{N}$ status (Xiong et al., 2003; Bai et al., 2004).

With the shrub expansion, $C$. microphylla could affect the productivity and diversity of associated plants because of its symbiotic $\mathrm{N}_{2}$-fixation. However, its $\mathrm{N}$ fixation and $\mathrm{N}$ transfer to associated non-legumes still remains unknown in these temperate grasslands. Clarifying these questions would be helpful for better understanding the role of $C$. microphylla in the $\mathrm{N}$ cycling of temperate grasslands. We hypothesize: 1 ) symbiotic $\mathrm{N}_{2}$-fixation by C. microphylla is significant on an annual scale in temperate grasslands; 2) the amount of $\mathrm{N}$ transferred to its associated species is species-specific and thereafter dependent upon their associated species. To test two hypotheses above, we chose $C$. microphylla shrubs growing together with four non-legumes (refer to as "mixed") and the same species growing without legumes (refer to as "pure") for in situ ${ }^{15} \mathrm{~N}$ labelling experiment in the temperate grassland in North of China.

\section{Materials and methods}

\subsection{Study site}

The field site lies in the southern margin of the farming-pastoral ecotone, Taibus Banner in Inner Mongolia of northern China $\left(41^{\circ} 35^{\prime} 50^{\prime \prime} \mathrm{N}, 114^{\circ} 51^{\prime} 45^{\prime \prime} \mathrm{E}, 1500 \mathrm{~m}\right.$ above sea level). The site is characterized by a semi-arid continental climate. In the past 35 years, the mean annual temperature and precipitation were $2.1^{\circ} \mathrm{C}$ and $384 \mathrm{~mm}$, respectively. The precipitation was concentrated in growing seasons (from the end of May to September), occupying $65 \%$ of the mean annual precipitation (Xu et al., 2014). The dominant plant species are Caragana microphylla, Artemisia capillaris, Artemisia frigida, Cleistogenes squarrosa, Stipa krylovii, Neopallasia pectinata, Allium polyrhizum and Leymus chinensis
(Table 1). A. capillaris, A. frigida, C. squarrosa and $L$. chinensis had the largest important values (IV) in the sampling plots (Table 1 ) were chosen as target species. Soils are chestnut soil (Chinese Soil Taxonomy Research Group, 2001), corresponding to Calcic Orthic Aridisol according to USDA Soil Taxonomy (Soil Survey Staff, 1987). The soil contains organic matter $2.7 \%$, total $\mathrm{N} 0.14 \%$, with $\mathrm{C} / \mathrm{N}$ ratio of 11.2 and soil $\mathrm{pH}$ 8.17. In the past 10 years since fenced by local government, these grasslands have been harvested at the end of October each year and used as winter forgrass for sheep, dairy cows or other livestocks.

A big plot $(400 \mathrm{~m} \times 50 \mathrm{~m})$ uniform in cover $(0.88 \pm 0.02)$ and species composition $\left(7 \pm 0.3\right.$ species $\mathrm{m}^{-2}$ ) (Table 1$)$ was selected for this experiment. A paired experimental design (shrub vs. nonshrub quadrats) was used. The experiment had a completely randomized block design. In the plots, eight paired shrub and nonshrub quadrats $(2 \mathrm{~m} \times 2 \mathrm{~m})$ were established. Each shrub quadrat (as "mixed") included the similar size of the legume C. microphylla and at least coexisting with four non-legume species (i.e. $C$. squarrosa, A. frigida, A. capillaris and $L$. chinensis). Each non-shrub quadrat (as "pure") included the same four non-legume species. The distance between paired quadrats was at least above $20 \mathrm{~m}$, while it was $5 \mathrm{~m}$ for quadrats within a paired quadrats. Among these paired quadrats, five used for ${ }^{15} \mathrm{~N}$ labeling and the rest of three used for spraying water as control. Totally, this experiment included eight paired quadrats (i.e. sixteen quadrats).

${ }^{15} \mathrm{~N}$ labelling was done on a sunny day, 1st August of 2013. $\mathrm{K}^{15} \mathrm{NO}_{3}\left(99.5 \%{ }^{15} \mathrm{~N}\right.$ enrichment) was dissolved with distilled water in a large sprayer and was sprayed randomly on five of eight paired quadrats, while the rest three paired quadrats were only sprayed with the same amount of distilled water as the control. To make no fertilization effect on plant growth, the $\mathrm{N}$ amount for ${ }^{15} \mathrm{~N}$ labeling was $0.03 \mathrm{~g} \mathrm{~m}^{-2}$. After the application of ${ }^{15} \mathrm{~N}$ tracer, additional amount of distilled water was sprayed to prevent ${ }^{15} \mathrm{~N}$ retained on the plant leaf surface. The total amount of added water was equal to about $3 \mathrm{~mm}$ of precipitation.

\subsection{Sampling and measurements}

An assumption of the ${ }^{15} \mathrm{~N}$ dilution technique is that the reference plants (i.e., non-legumes) and legumes would take up the same $\mathrm{N}$ source from soil regardless of whether they grew alone or with a legume (Chalk et al., 2014). In this study, four nonlegumes, i.e. A. capillaris, A. frigida, C. squarrosa and L. chinensis, growing with $C$. microphylla, were selected as reference plants. All reference plants and legumes are perennial, $A$. frigida and $A$. capillaris belong to Compositae showing similar phenology with $C$. microphylla, and C. squarrosa and L. chinensis belong to Graminoids.

One month after ${ }^{15} \mathrm{~N}$ labelling, aboveground part of $C$. microphylla and reference plants (i.e., C. squarrosa, A. frigida, A. capillaris and $L$. chinensis) in both labeled and controlled quadrats were harvested. They were dried for $48 \mathrm{~h}$ at $65^{\circ} \mathrm{C}$ after washed carefully by distilled water. All aboveground plant materials were ground to a fine powder by a ball mill (MM200, Fa. Retsch, Haan, Germany) for measurements of $\mathrm{N}$ content (\%) and ${ }^{15} \mathrm{~N} /{ }^{14} \mathrm{~N}$ ratios.

Table 1

The Cover, frequency, height and important value of plant species in the temperate grasslands.

\begin{tabular}{|c|c|c|c|c|c|}
\hline Species & Cover & Frequency & Height $(\mathrm{cm})$ & IV & Order of IV \\
\hline Cleistogenes squarrosa & $0.33 \pm 0.18$ & 0.93 & $10.38 \pm 3.78$ & 0.102 & 1 \\
\hline Artemisia frigida & $0.31 \pm 0.22$ & 0.80 & $20.18 \pm 7.00$ & 0.098 & 2 \\
\hline Artemisia capillaris & $0.23 \pm 0.19$ & 0.90 & $27.28 \pm 5.59$ & 0.096 & 3 \\
\hline Leymus chinensis & $0.14 \pm 0.12$ & 0.78 & $21.02 \pm 5.09$ & 0.071 & 4 \\
\hline Stipa krylovii & $0.08 \pm 0.08$ & 0.50 & $44.65 \pm 14.15$ & 0.064 & 5 \\
\hline Neopallasia pectinata & $0.17 \pm 0.26$ & 0.15 & $33.20 \pm 8.02$ & 0.053 . & 6 \\
\hline Allium polyrhizum & $0.07 \pm 0.05$ & 0.65 & $17.77 \pm 4.62$ & 0.053 & 7 \\
\hline
\end{tabular}


Three additional quadrats close to the sampling quadrats were selected to estimate the aboveground and belowground biomass of C. microphylla and reference plants. All aboveground biomass were clipped close to the soil surface and classified by species. All belowground biomass were obtained by digging up to $15 \mathrm{~cm}$ depth for reference plants and $1 \mathrm{~m}$ depth for $C$. microphylla. Five cores ( $0-$ $15 \mathrm{~cm}$ depth) of composite soil samples in each quadrat were collected from four corners and the center of each quadrat with a soil probe $(2.8 \mathrm{~cm}$ in diameter). The fresh soil samples were processed with $2 \mathrm{~mm}$ mesh to remove coarse fragments and for measuring soil basic characteristics.

About $2 \mathrm{mg}$ of plant materials were weighed into tin capsules to analyze ${ }^{15} \mathrm{~N} /{ }^{14} \mathrm{~N}$ by continuous-flow gas isotope ratio mass spectrometry (MAT253, Finnigan MAT, Bremen, Germany), coupled by ConFlo III device (Finnigan MAT, Bremen, Germany) to an elemental analyzer (EA 1112, CE Instruments, Milan, Italy). Atmospheric $\mathrm{N}_{2}$ was used as standard. The standard deviation of repeated measurements of laboratory standards was $\pm 0.15 \%$. Soil organic matter was measured with wet oxidation by acid dichromate solution described by Kalembasa and Jenkinson (1973). Total $\mathrm{N}$ was determined by Kjeldahl digestion with a salicylic acidification (Pruden et al., 1984). Soil pH was measured by a glass electrode with a 1:2.5 soil to water ratio.

\subsection{Calculations}

The $\mathrm{N}$ derived from the atmosphere (\%Ndfa) for $C$. microphylla was calculated by the following equation (Vallis et al., 1967):

$\% \mathrm{Ndfa}=\left(1-\frac{\mathrm{APE}_{\mathrm{leg}(\mathrm{m})}}{\mathrm{APE}_{\text {reference }(\mathrm{m})}}\right) \times 100$

where APE was calculated as atom $\%{ }^{15} \mathrm{~N}$ difference between the same plant species from ${ }^{15} \mathrm{~N}$-labelled and controled quadrats. $\mathrm{APE}_{\text {leg(m) }}$ indicates APE for $C$. microphylla, $\mathrm{APE}_{\text {reference }(\mathrm{m})}$ indicates APE for reference plants in the mixed quadrats.

The amount of $\mathrm{N}$ fixed by $C$. microphylla $\left(\mathrm{N}_{\text {fixed }}, \mathrm{g} \mathrm{m}^{-2}\right.$ ) was calculated by the following equation (Busse, 2000):

$\mathrm{N}_{\text {fixed }}=\% \mathrm{Ndfa} \times$ Biomass $_{\text {leg }} \times \mathrm{N}_{\text {leg }}$

where the \%Ndfa indicates the $\mathrm{N}$ derived from the atmosphere for C. microphylla, the Biomass $\mathrm{seg}_{\mathrm{leg}}\left(\mathrm{g} \mathrm{m}^{-2}\right)$ indicates the aboveground biomass of $C$. microphylla, $\mathrm{N}_{\mathrm{leg}}(\%)$ indicates $\mathrm{N}$ content in aboveground part of $C$. microphylla.

The percent of non-legume $\mathrm{N}$ in a mixed quadrat transferred from C. microphylla (\% $\mathrm{N}_{\text {transfer }}$ ) was calculated by the following equation (Chalk, 1985):

$\% \mathrm{~N}_{\text {transfer }}=\left(1-\frac{\operatorname{APE}_{\text {reference }(\mathrm{m})}}{\operatorname{APE}_{\text {reference }(\mathrm{p})}}\right) \times 100$

where $A P E_{\text {reference }(m)}$ represents APE for non-legumes in the mixed quadrats, $A P E_{\text {reference(p) }}$ represents APE for non-legume species in the pure quadrats without $C$. microphylla.

The amount of $\mathrm{N}$ transferred from $C$. microphylla to nonlegumes $\left(\mathrm{N}_{\text {transfer, }} \mathrm{g} \mathrm{m}^{-2}\right.$ ) was caculated as the following equation (Chalk, 1985):

$\mathrm{N}_{\text {transfer }}=\% \mathrm{~N}_{\text {transfer }} \times$ Biomass $_{\text {non-leg }} \times \mathrm{N}_{\text {non-leg }}$

where $\% \mathrm{~N}_{\text {transfer }}$ refers to the percent of non-legume $\mathrm{N}$ in mixed quadrats transferred from C. microphylla, Biomass ${ }_{\text {non-leg }}\left(\mathrm{g} \mathrm{m}^{-2}\right)$ refers to the aboveground biomass of non-legumes, and $\mathrm{N}_{\text {non-leg }}(\%)$ refers to the $\mathrm{N}$ content in aboveground part of non-legumes.

The standard errors (SE) of means are presented in Figures and Tables as a variability parameter. One-way analysis of variance (ANOVA) was carried out with LSD test to determine effects of

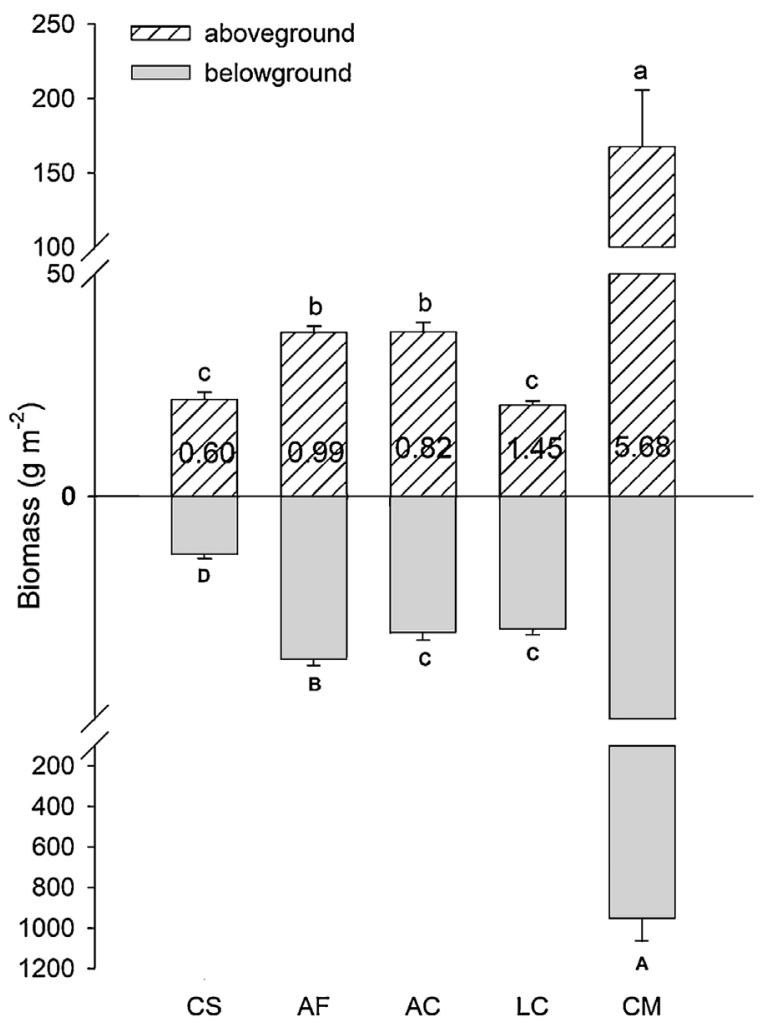

Fig. 1. Biomass and root to shoot ratio of the four non-legumes and legume in a temperate grassland of North China, and error bars show means $\pm S E(n=3)$. Different lowercase and capital letters represent significant difference at $p<0.05$ among aboveground biomass and belowground biomass of the five plant species, respectively. The values in the histogram represent the root to shoot ratio of each plant species. CS, Cleistogenes squarrosa; AF, Artemisia frigida; AC, Artemisia capillaris; LC, Leymus chinensis; CM, Caragana microphylla.

plant species on aboveground and belowground biomass, effects of legume on $\mathrm{N}$ content and $\delta^{15} \mathrm{~N}$ of non-legumes in the mixed quadrats of natural condition, the\%Ndfa and $\mathrm{N}$ transfer from symbiotic $\mathrm{N}_{2}$-fixation by legume. Paired $t$-test was used to analyze the difference in APE between legume and reference plants in the mixed quadrats. All the tests were run by using SPSS 20.0 software package (SPSS Inc. Chicago, IL, USA). Significance was considered at $p<0.05$.

\section{Results}

\subsection{Biomass and root to shoot ratio in the temperate grassland}

Total aboveground biomass for all plants averaged $284 \pm 44 \mathrm{~g}$ $\mathrm{m}^{-2}$ in the mixed C. microphylla community (Fig. 1, Table 2). Aboveground biomass of $C$. microphylla was about $168 \pm 38 \mathrm{~g} \mathrm{~m}^{-2}$, about $59 \%$ of total aboveground biomass in the mixed legume community. The aboveground biomass of $A$. capillaris and A. frigida was higher than that of $C$. squarrosa and L. chinensis (Fig. 1, Table 2).

Total belowground biomass of all plants in the mixed $C$. microphylla community was about $1063 \pm 117 \mathrm{~g} \mathrm{~m}^{-2}$ (Fig. 1), and $C$. microphylla contributed about $90 \%$ of total belowground biomass. The belowground biomass of the four non-legumes differred significantly $\left(F_{(3,8)}=46.12, p<0.05\right)$. That of $A$. frigida was higher than that of the other three non-legumes $\left(F_{(3,8)}=46.12, p<0.05\right)$, and $C$. squarrosa had the minimum belowground biomass (Fig. 1, Table 2).

Root to shoot ratio of $C$. microphylla $(5.68 \pm 1.1)$ was significantly higher than that of the four non-legumes (Fig. 1, $F_{(4,10)}=20.459$, $p<0.05$ ). For the four non-legumes, root to shoot ratios of $C$. 
Table 2

The APE, $\mathrm{N}$ content and aboveground biomass of plants in the temperate grasslands of North China.

\begin{tabular}{|c|c|c|c|c|c|}
\hline \multirow[t]{2}{*}{ Species } & \multicolumn{2}{|l|}{ APE (\%) } & \multicolumn{2}{|c|}{$\mathrm{N}$ content (\%) } & \multirow{2}{*}{$\begin{array}{l}\text { Aboveground Biomass }\left(\mathrm{g} \mathrm{m}^{-2}\right) \\
\text { Mixed }\end{array}$} \\
\hline & Pure & Mixed & Pure & Mixed & \\
\hline Cleistogenes squarrosa & $0.335 \pm 0.048$ & $0.156 \pm 0.014$ & $1.20 \pm 0.08$ & $1.64 \pm 0.10$ & $21.85 \pm 1.63$ \\
\hline Artemisia frigida & $0.337 \pm 0.074$ & $0.210 \pm 0.005$ & $1.82 \pm 0.05$ & $1.92 \pm 0.21$ & $36.88 \pm 1.72$ \\
\hline Artemisia capillaris & $0.525 \pm 0.071$ & $0.336 \pm 0.046$ & $1.37 \pm 0.05$ & $1.93 \pm 0.06$ & $37.01 \pm 2.18$ \\
\hline Leymus chinensis & $0.104 \pm 0.017$ & $0.144 \pm 0.025$ & $1.24 \pm 0.05$ & $2.09 \pm 0.06$ & $20.56 \pm 0.92$ \\
\hline Caragana microphylla & - & $0.018 \pm 0.002$ & - & $2.83 \pm 0.16$ & $167.69 \pm 38.13$ \\
\hline
\end{tabular}

Pure indicates the reference plants growing without legume; Mixed indicates the reference plants growing with legume; - indicates no data.

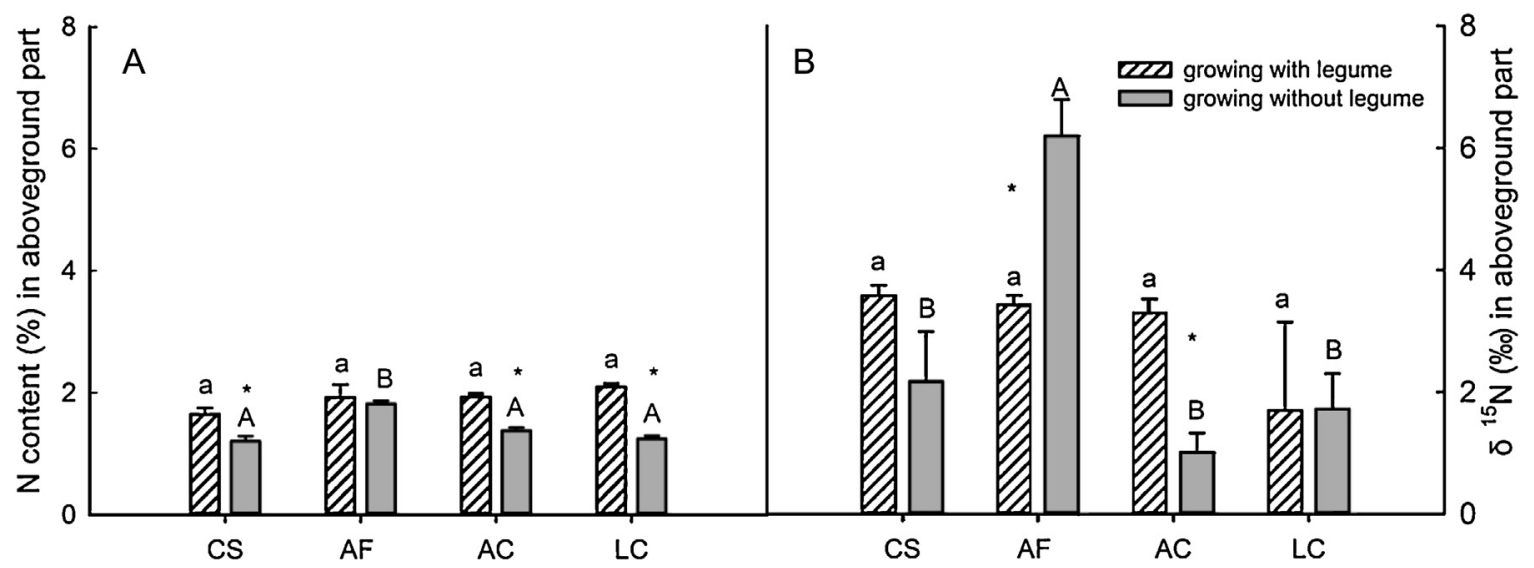

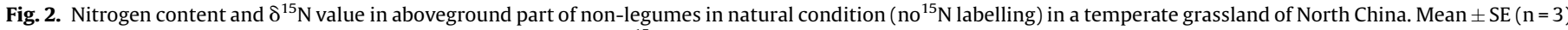

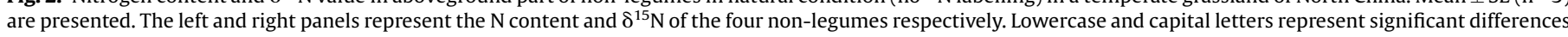

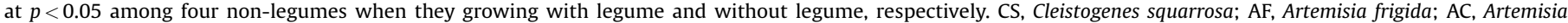
capillaris; LC, Leymus chinensis. The asterisk represents the significant difference at $p<0.05$, when the same non-legume grow with and without legume.

squarrosa, $A$. capillaris and $A$. frigida are less than one, while that of L. chinensis is larger than one (Fig. 1).

\subsection{Nitrogen content and $\delta^{15}$ in aboveground part of C. microphylla and non-legumes}

Aboveground $\mathrm{N}$ content of non-legumes growing with the legume was obviously higher than those growing without the legume except for $A$. frigida (Fig. 2A, Table 2, $F_{(1,22)}=18.08$, $p<0.05)$. Similar pattern of higher $\mathrm{N}$ content was found for the four reference plants when growing with legume than growing alone. $\mathrm{N}$ content of $A$. frigida was higher than the other three nonlegumes (Table 2). In the $C$. microphylla community, the $\mathrm{N}$ stock in the aboveground biomass was estimated to be $7.73 \mathrm{~g} \mathrm{~m}^{-2}$, while that of belowground root biomass in $1 \mathrm{~m}$ depth was estimated to be $35 \mathrm{~g} \mathrm{~m}^{-2}$.

Aboveground $\delta^{15} \mathrm{~N}$ values of the four non-legumes growing with C. microphylla were similar (Fig. 2B). When they grow alone, $A$. frigida was significantly higher than the other three non-legumes $\left(F_{(3,8)}=14.8, p<0.05\right.$, Fig. 2B). The aboveground $\delta^{15} \mathrm{~N}$ of $A$. frigida $\left(F_{(1,4)}=19.885, p<0.05\right)$ and A. capillaris $\left(F_{(1,4)}=34.287, p<0.05\right)$ differed greatly when they grow with or without $C$. microphylla (Fig. 2B).

3.3. APE in aboveground part of non-legumes and $N$ derived from the atmosphere

The APE for reference plants in aboveground part was distinctly higher than that of $C$. microphylla $(0.21 \%$ vs $0.02 \%, t=10.4, p<0.001$, Fig. 3). A. capillaris exhibited significantly higher APE $(0.34 \% \pm 0.05)$ than the other three reference plants $\left(F_{(3,16)}=9.80, p<0.05\right)$. In contrast, significant difference was found in APE between $C$ squarrosa, L. chinensis and A. frigida (Fig. 3, $F_{(2,12)}=3.237, p>0.05$ ).

The \%Ndfa of $C$. microphylla was estimated to range from 84 to 95\% (averaged 90\%). Based on the aboveground biomass and its $\mathrm{N}$ content, the amount of $\mathrm{N}$ fixed by $\mathrm{C}$. microphylla was conservatively estimated to be about $4.3 \mathrm{~g} \mathrm{~N} \mathrm{~m}^{-2} \mathrm{yr}^{-1}$.

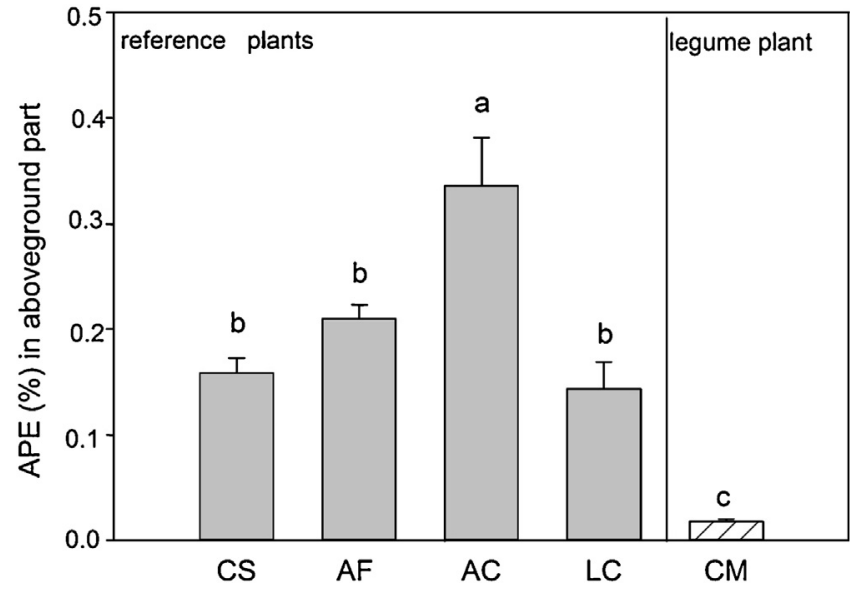

Fig. 3. The APE in aboveground part of legume and reference plants in ${ }^{15} \mathrm{~N}$ labeling quadrats in a temperate grassland of North China. Mean $\pm \operatorname{SE}(n=5)$ are presented. Different letters represent significant differences at $p<0.05$ among five plants in the temperate grassland. CS, Cleistogenes squarrosa; AF, Artemisia frigida; AC, Artemisia capillaris; LC, Leymus chinensis; CM, Caragana microphylla. 


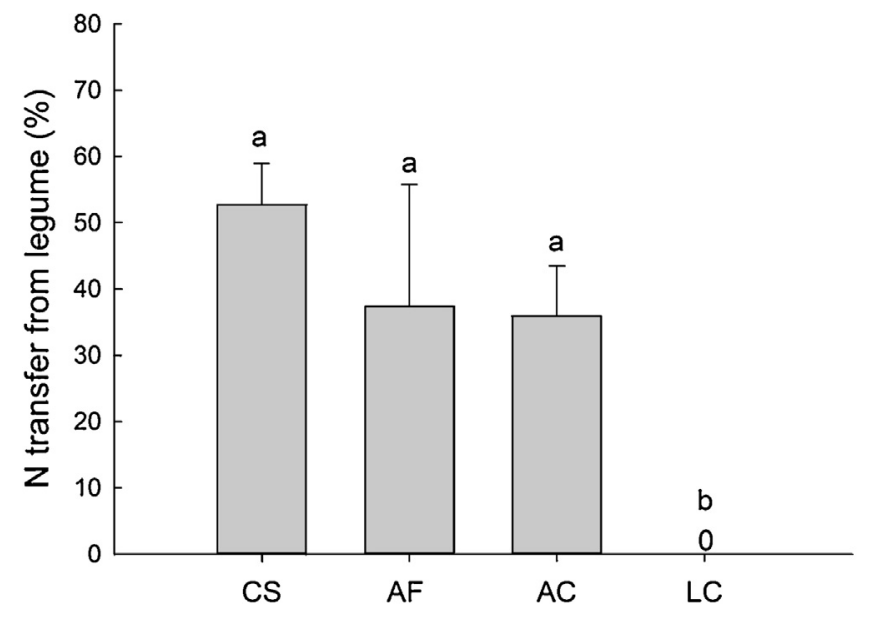

Fig. 4. Percentage of non-legume $\mathrm{N}$ in aboveground part transferred from legume in the temperate grassland. Mean $\pm S E(n=5)$ are presented. Different letters represent significant differences at $p<0.05$ between the four non-legumes in the temperate grassland. CS, Cleistogenes squarrosa; AF, Artemisia frigida; AC, Artemisia capillaris; LC, Leymus chinensis.

\subsection{Nitrogen in aboveground part of non-legumes transferred from $\mathrm{C}$. microphylla}

The aboveground $\mathrm{N}$ amount in the non-legumes transferred from C. microphylla varied as different non-legume species growing with C. microphylla (Fig. 4). About half amount of aboveground $\mathrm{N}$ for $C$. squarrosa derived from $C$. microphylla, but there is no significant difference among $A$. frigida, $A$. capillaris and $C$. squarrosa $\left(F_{(2,12)}=0.009, p>0.05\right)$. By comparison, L. Chinensis almost did not obtains any $\mathrm{N}$ from its associated $\mathrm{C}$. microphylla (Fig. 4).

\section{Discussion}

With ${ }^{15} \mathrm{~N}$ dilution approach, we quantified the amount of $\mathrm{N}$ fixed by legume shrub of $C$. microphylla as well as its $\mathrm{N}$ transfer to coexisting non-legume species in the temperate grassland of northern China. We found that the \%Ndfa of C. microphylla was about $90 \%$, falling within estimated ranges (85-92) by previous observations in similar temperate grasslands (Yang et al., 2011). Given the \%Ndfa reflects the proportion of $\mathrm{N}$ derived from the atmosphere through biological $\mathrm{N}$ fixation by legumes (Vallis et al., 1967; Temperton et al., 2007; Carlsson et al., 2009), our estimate indicate that the shrub legume mainly relies on its symbiotic fixation of atmospheric N. The choice of reference plants could influence the estimate accuracy of \%Ndfa (Rennie et al., 1982; Holdensen et al., 2007), but a recent study proved the reference plants growing together with legumes can provide a more relatively reliable quantification of $\mathrm{N}_{2}$-fixation (Carlsson and Huss-Danell, 2014). To reduce the uncertainties in estimate of the\%Ndfa, we totally chose four non-legumes as reference plants.

It is well known that legumes are more competitive in the $\mathrm{N}$ limited ecosystems than non-legumes due to their symbiotic $\mathrm{N}_{2}$ fixation, e.g. \%Ndfa values for legumes growing in soils of low $\mathrm{N}$ availability can be up to $90 \%$ (Turner and Bergersen, 1983; Ledgard et al., 1987). Such atmospheric $\mathrm{N}_{2}$ fixation provides advantage for the legumes in $\mathrm{N}$-limited habitats, because to some degree it reduces the competition for soil inorganic $\mathrm{N}$ between legumes and other non-legume species. Further, legumes improve the quality and quantity of soil nutrients through providing extra $\mathrm{N}$ in temperate grasslands (Murray and Clements, 1988; Paynel et al., 2001 ). Due to its N fixation, C. microphylla shrubs even could grow in bare soils and regulate population dynamics of herbaceous plants at individual shrub scale in temperate grasslands (Koyama et al., 2015; Guan et al., 2015). Therefore, they are often widely used as a pioneer species in vegetation reestablishment in the degraded grasslands (Guan et al., 2015). Our results partly confirmed that $C$. microphylla would be more easily survive in degraded grasslands.

The amount of $\mathrm{N}$ fixed by $\mathrm{C}$. microphylla was estimated to be about $4.3 \mathrm{~g} \mathrm{~N} \mathrm{~m}^{-2}$, similar with those estimated by Issah et al. (2014) for Caragana $\left(4.12 \mathrm{~g} \mathrm{~m}^{-2}\right)$ in Canada with the same technique. Despite the similar \%Ndfa, the $\mathrm{N}$ fixed by $C$. microphylla is much larger than that of other legumes in temperate Leymus steppes (Li et al., 2002; Yang et al., 2011). This is mainly ascribed to the higher biomass of $C$. microphylla shrub. However, our estimate was less than that $\left(15.5 \mathrm{~g} \mathrm{~m}^{-2}\right.$ ) of white clover (Trifolium repens) growing in mixture with ryegrass (Lolium perenne) (Nutman, 1971). Possible explanation is that the potential of $\mathrm{N}$ fixation by legumes (Sanford et al., 1995; Carlsson and Huss-Danell, 2003) maybe differs between species, and the higher temperature and soil moisture for white clover could lead to a higher total $\mathrm{N}$ yield in the grass-clover mixture (Sanford et al., 1995). Growing in the semiarid area of northern China, C. microphylla has a well-developed root system and associated with an increase in\%Ndfa compared to white clover (Ledgard et al., 1987). This may possibly due to the special characteristics of legume plants (e.g. with mycorrhizal symbiotic systems). We inferred that the $\mathrm{N}$ fixed by $C$. microphylla in our studied temperate grassland would account for $75 \%$ of the gap of $\mathrm{N}$ demand and supply with the same method used by Yang et al. (2011). This indicated that biological $\mathrm{N}_{2}$-fixation of $C$. microphylla plays a more important role in $\mathrm{N}$ dynamics in $\mathrm{N}$-limited grasslands. Shearer and Kohl (1986) suggested that biological N fixation by legumes ranged from 4 to $40 \mathrm{~g} \mathrm{~N} \mathrm{~m}^{-2} \mathrm{yr}^{-1}$, and could achieve $46 \%$ of the total $\mathrm{N}$ accumulation of all the aboveground plant biomass. Biological $\mathrm{N}$ fixation by C. microphylla can contribute $56 \%$ of the total $\mathrm{N}$ stock in the grasslands. This indicates that C. microphylla is an important plant species in maintaining ecosystem functions, supporting our first hypothesis that symbiotic $\mathrm{N}_{2}$-fixation by $C$. microphylla is important on an annual scale in temperate grasslands. Especially due to the removal of aboveground biomass by overgrazing, the plants are often limited by the soil available $\mathrm{N}$ in temperate grasslands (Yan et al., 2014).

Symbiotic $\mathrm{N}$ fixation provides an important $\mathrm{N}$ source for those coexisting non-legumes (Pirhofer-Walzl et al., 2012). A fraction of $\mathrm{N}$ fixed by legumes can be transferred to their associated grasses (Ledgard and Steele, 1992; Sierra and Daudin, 2010; Makarov et al., 2011; Carlsson and Huss-Danell, 2014). For example, Ledgard (1991) found that $22 \%$ of $\mathrm{N}$ fixed by white clover was transferred to associated plants. Brophy et al. (1987) showed that $68 \%$ of $\mathrm{N}$ in Phalaris arundinacea derived from Medicago sativa and obtained $17 \%$ of $\mathrm{N}$ fixed by $M$. sativa. In this study, half of $C$. squarrosa aboveground $\mathrm{N}$ derived from $C$. microphylla. The legume $C$. microphylla transferred approximately $4.4 \%, 6.2 \%$ and $6.0 \%$ of its aboveground fixed $\mathrm{N}$ to $C$. squarrosa, A. frigida and A. capillaris, respectively. $L$. chinensis did not show $\mathrm{N}$ acquisition from $C$. microphylla. This reflects that $\mathrm{N}$ transferred from legumes to nonlegumes varies in non-legume species, confirming our second hypothesis that the amount of $\mathrm{N}$ transferred to its associated species could be species-specific and mostly depended upon their associated species. Coexisting non-legume species can acquire $\mathrm{N}$ fixed by legumes mainly through mycorrhizal networks between their roots and legume roots (Jalonen et al., 2009), by absorption of mineralized N derived from dead root nodules (Butler et al., 1959; Pirhofer-Walzl et al., 2011), or by uptake of $\mathrm{N}$ compounds exuded directly by legume roots (Ta et al., 1986; Jiang and Zhai 2000). Therefore, the difference in $\mathrm{N}$ transfer could be ascribed to the root characteristics and regrowth strategies of plant species (Temperton et al., 2007; Pirhofer-Walzl et al., 2012), the distance between legumes and non-legumes (Issah et al., 2015) and the N status in soil (Murray et al., 2008). The root architectures and regrowth 
strategies of non-legume species (Pirhofer-Walzl et al., 2012) partly explain the reason for the difference in their $\mathrm{N}$ content and $\delta{ }^{15} \mathrm{~N}$ when they growing with the legume shrubs and growing alone. Given that only about $17 \%$ of fixation N from C. microphylla was transferred to associated species, this indicates that most $\mathrm{N}$ fixed by the legume was used for themselves' growth and production. Nonetheless, non-legumes can benefit from their associated $C$. microphylla, and the survival of $C$. microphylla in degraded grasslands is very important for their coexisting nonlegumes.

The $\mathrm{N}$ transferred to non-legumes in this study was assessed only based on the ${ }^{15} \mathrm{~N}$ in the aboveground plant parts. This actually underestimated the amount of $\mathrm{N}$ fixed by the shrub legume and its $\mathrm{N}$ transfer to non-legumes. Further studies should be done to clarify the magnitude on intact plant individuals and the potential effect derived from shrub ages.

\section{Conclusion}

Symbiotic $\mathrm{N}_{2}$-fixation and transfer to non-legumes was estimated based on the aboveground biomass and its ${ }^{15} \mathrm{~N}$. The $\%$ Ndfa of $C$. microphylla in temperate grasslands was about $90 \%$. Total $\mathrm{N}$ fixation in aboveground part of $C$. microphylla community was estimated to be about $4.3 \mathrm{~g} \mathrm{~N} \mathrm{~m}^{-2} \mathrm{yr}^{-1}$. About half of $\mathrm{N}$ in aboveground part of $C$. squarrosa derived from C. microphylla, while L. chinensis almost did not benefit from C. microphylla. Totally, about $17 \%$ of $\mathrm{N}$ fixed by C. microphylla was transferred to its associated species. Since C. microphylla is widespread and predominant in the arid and semi-arid area of northern China, their symbiotic $\mathrm{N}_{2}$-fixation makes more significant contributions to the $\mathrm{N}$ economy of temperate grassland ecosystems. These findings indicate that $C$. microphylla is an important plant species that can strongly modify the $\mathrm{N}$ cycling due to its $\mathrm{N}$ fixation and transfer in temperate grasslands in North China.

\section{Acknowledgements}

This research was supported by the National Key Basic Research Program of China (Grant No. 2014CB138803), and the National Key Research and Development Program of China (Grant No. 2016YFC0500502), Fundamental Research Funds for the Central Universities (Grant No. 2014KJJCB01), as well as National Natural Science Foundation of China (31470560, 31570468 and 31270500).

\section{References}

Bai, Y.F., Han, X.G., Wu, J.G., Chen, Z.Z., Li, L.H., 2004. Ecosystem stability and compeansatory effects in the Inner Mongolia grassland. Nature 431, 181-184.

Brophy, L.S., Heichel, G.H., Russelle, M.P., 1987. Nitrogen transfer from forage legumes to grass in a systematic planting design Crop. Science 27, 753-758.

Busse, M.D., 2000. Suitability and use of the ${ }^{15} \mathrm{~N}$-isotope dilution method to estimate nitrogen fixation by actinorhizal shrubs. For. Ecol. Manag. 136 (1-3), $85-95$.

Butler, G.W., Greenwood, R.M., Soper, K., 1959. Effects of shading and defoliation on the turnover of root and nodule tissue of plants of Trifolium repens, Trifolium pratense, and Lotus uliginosus. N. Z. J. Agric. Res. 2 (3), 415-426.

Carlsson, G., Huss-Danell, K., 2003. Nitrogen fixation in perennial forage legumes in the field. Plant Soil 253 (2), 353-372.

Carlsson, G., Huss-Danell, K., 2014. Does nitrogen transfer between plants confound ${ }^{15} \mathrm{~N}$-based quantifications of $\mathrm{N}_{2}$ fixation? Plant Soil 374 (1-2), 345-358.

Carlsson, G., Palmborg, C., Jumpponen, A., Scherer-Lorenzen, M., Högberg, P., HussDanell, K., 2009. $\mathrm{N}_{2}$ fixation in three perennial Trifolium species in experimental grasslands of varied plant species richness and composition. Plant Ecol. 205 (1), 87-104.

Chalk, P.M., Peoples, M.B., McNeill, A.M., Boddey, R.M., Unkovich, M.J., Gardener, M. J., Silva, C.F., Chen, D.L., 2014. Methodologies for estimating nitrogen transfer between legumes and companion species in agro-ecosystems: a review of ${ }^{15} \mathrm{~N}$ enriched techniques. Soil Biol. Biochem. 73, 10-21.

Chalk, P.M., 1985. Estimation of $\mathrm{N}_{2}$ fixation by isotope dilution: an appraisal of techniques involving ${ }^{15} \mathrm{~N}$ enrichment and their application. Soil Biol. Biochem. 17 (4), 389-410.
Chinese Academy of Sciences, 2001. The Chinese Soil Taxonomic Classification Retrieval, third edition Press of University of Science and Technology of China, Hefei.

Chu, Y., Yang, H.L., Zhu, X.W., Dong, M., 2005. Spatial heterogeneity of Caragana microphylla shrub communities in the Otindag Sandland. Acta Ecol. Sin. 25 (12), 3294-3300.

Cusack, D.F., Silver, W., McDowell, W.H., 2009. Biological nitrogen fixation in two tropical forests: ecosystem-level patterns and effects of nitrogen fertilization. Ecosystems 12 (8), 1299-1315.

Gao, Y.Z., Han, X.G., Wang, S.P., 2004. The effects of grazing on grassland soils. Acta Ecol. Sin. 24 (4), 790-797.

Guan, P.T., Zhang, X.K., Yu, J., Ma, N.N., Liang, W.J., 2015. Variation of soil nematode community composition with increasing sand-fixation year of Caragana microphylla: bioindication for desertification restoration. Ecol. Eng. 81, 93-101.

Høgh-Jensen, H., Schjoerring, J., 2000. Below-ground nitrogen transfer between different grassland species: direct quantification by ${ }^{15} \mathrm{~N}$ leaf feeding compared with indirect dilution of soil ${ }^{15} \mathrm{~N}$. Plant Soil 227 (1-2), 171-183.

Hauggaard-Nielsen, H., Ambus, P., Jensen, E.S., 2001. Interspecific competition, N use and interference with weeds in pea-barley intercropping. Field Crops Res. 70 (2), 101-109.

Herridge, D.F., Peoples, M.B., Boddey, R.M., 2008. Global inputs of biological nitrogen fixation in agricultural systems. Plant Soil 311 (1-2), 1-18.

Holdensen, L., Hauggaard-Nielsen, H., Jensen, E.S., 2007. Short-range spatial variability of soil ${ }^{\delta 15} \mathrm{~N}$ natural abundance-effects on symbiotic $\mathrm{N}_{2}$-fixation estimates in pea. Plant Soil 298 (1-2), 265-272.

Issah, G., Kimaro, A.A., Kort, J., Knight, J.D., 2014. Quantifying biological nitrogen fixation of agroforestry shrub species using ${ }^{15} \mathrm{~N}$ dilution techniques under greenhouse conditions. Agrofor. Syst. 88 (4), 607-617.

Issah, G., Kimaro, A.A., Kort, J., Knight, J.D., 2015. Nitrogen transfer to forage crops from a Caraganashelterbelt. Forest 6 (6), 1922-1932.

Jalonen, R., Nygren, P., Sierra, J., 2009. Root exudates of a legume tree as a nitrogen source for a tropical fodder grass. Nutr. Cycl. Agroecosyst. 85 (2), 203-213.

Jiang, S.N., Zhai, M.P., 2000. Nitrogen transfer between $\mathrm{N}_{2}$-fixting plant and non- $\mathrm{N}_{2}-$ fixing plant. J. For. Res. 11, 75-80.

Kalembasa, S.J., Jenkinson, D.S., 1973. A comparative study of titrimetric and gravimetric methods for the determination of organic carbon in soil. J. Sci. Food Agric. 24 (9), 1085-1090.

Koyama, A., Sasaki, T., Jamsran, U., Okuro, T., 2015. Shrub cover regulates population dynamics of herbaceous plants at individual shrub scale on the Mongolian steppe. J. Veg. Sci. 26 (3), 441-451.

Lebauer, D.S., Treseder, K.K., 2008. Nitrogen limitation of net primary productivity in terrestrial ecosystems is globally distributed. Ecology 89 (2), 371-379.

Ledgard, S.F., Steele, K.W., 1992. Biological nitrogen fixation in mixed legume/grass pastures. Plant Soil 141 (1-2), 137-153.

Ledgard, S.F., Brier, G.J., Littler, R.A., 1987. Legume production and nitrogen fixation in hill pasture communities. N. Z. J. Agric. Res. 30 (4), 413-442.

Ledgard, S.F., 1991. Transfer of fixed nitrogen from white clover to associated grasses in swards grazed by dairy cows, estimated using ${ }^{15} \mathrm{~N}$ methods. Plant Soil 131 (2), $215-223$.

Li, X.Z., Zhang, S.M., Xiong, X.R., 2002. Spatial variation of plant biomass and soil chemical element contents induced by Catagana microphylla. Acta Prarm. Sin. 11 (1), 1-3.

Li, X.H., Jiang, D.M., Luo, Y.M., 2010. Soil fertile islands of shrub canopy and impacts on vegetation in chronosequence of Caragana microphylla. J. Liaon. Technol. Univ. (Nat. Sci.) 29 (2), 336-339.

Makarov, M.I., Malysheva, T.I., Ermak, A.A., Onipchenko, V.G., Stepanov, A.L., Menyailo, O.V., 2011. Symbiotic nitrogen fixation in the alpine community of a lichen heath of the Northwestern Caucasus Region (the Teberda Reserve). Eur. Soil Sci. 44 (12), 1381-1388.

Moukoumi, J., Farrell, R.E., van Rees, K.J.C., Hynes, R.K., Belanger, N., 2012. Growth and nitrogen dynamics of juvenile short rotation intensive cultures of pure and mixed Salix miyabeana and Caragana arborescens. Biol. Res. 5, 719-732.

Murray, P.J., Clements, R.O., 1998. Transfer of nitrogen between clover and wheat: effectofrootherbivory. Eur. J. Soil Biol. 34 (1), 25-30.

Murray, U., Herridge, D., Peoples, M., Cadisch, G., Boddey, B., Giller, K., Alves, B. Chalk, P., 2008. Measuring plant-associated nitrogen fixation in agricultural systems. ACIAR Monograph No. 132, 163-217.

Niu, S.L., Jiang, G.M., 2004. The importance of legume in China grassland ecosystem and advances in physiology and ecology studies. Chin. Bull. Bot. 21 (1), 9-18.

Nutman, P.S., 1971. Perspectives in biological nitrogen fixation. ScienceProgress (Oxford) 59, 55-74.

Paynel, F., Murray, P.J., Cliquet, J.B., 2001. Root exudates: a pathway for short-term N transfer from clover and ryegrass. Plant Soil 229 (2), 235-243.

Peoples, M.B., Herridge, D.F., Ladha, J.K., 1995. Biological nitrogen fixation: an efficient source of nitrogen for sustainable agricultural production? Plant Soil 174 (1-2), 3-28.

Peoples, M.B., Boddy, R.M., Herridge, D.F., 2002. Quantification of nitrogen fixation. In: Leigh, G.J. (Ed.), Nitrogen Fixation at the Millennium. Elsevier, Amsterdam, pp. 357-389.

Pirhofer-Walzl, K., Rasmussen, J., Høgh-Jensen, H., Eriksen, J., Søegaard, K., Rasmussen, J., 2012. Nitrogen transfer from forage legumes to nine neighboring plants in a multi-species grassland. Plant Soil 350 (1), 71-84.

Pollock, T., Svendsen, E., 2008. Trees and Shrubs for Agroforestry on the Prairies: Adapted Species Available Through the Prairie Shelterbelt Program. Agriculture and Agri-Food Canada Indian Head, SK, 31. 
Pruden, G., Powlson, D.S., Jenkinson, D.S., 1984. The measurement of ${ }^{15} \mathrm{~N}$ in soil and plant material. Fert. Res. 6 (3), 205-218.

Rennie, R.J., Dubetz, S., Bole, J.B., Muendel, H.H., 1982. Denitrogen fixation measured by ${ }^{15} \mathrm{~N}$ isotope dilution in two Canadian soybean cultivars. Agro. J. 74, 729-730.

Sanford, P., Pate, J.S., Unkovitch, M.J., Thompson, A.N., 1995. Nitrogen fixation in grazed and ungrazed subterranean clover pasture in south west Australia assessed by the ${ }^{15} \mathrm{~N}$ natural abundance technique. Aust. J. Agric. Res. 46, 14271443.

Schlesinger, W.H., Pilmanis, A.M., 1998. Plant-soil interactions in deserts. Biogeochemistry 42, 169-187.

Shearer, G., Kohl, D.H., 1986. $\mathrm{N}_{2}$-fixation in field settings-estimation based on natural ${ }^{15} \mathrm{~N}$ abundance. Aust. J. Plant Physiol. 13 (6), 699-756.

Sierra, J., Daudin, D., 2010. Limited ${ }^{15} \mathrm{~N}$ transfer from stem-labeled leguminous trees to associated grass in an agroforestry system. Eur. J. Agron. 32 (3), 240-242.

Sierra, J., Nygren, P., 2006. Transfer of N fixed by a legume tree to the associated grass in a tropical silvopastoral system. Soil Biol. Biochem. 38 (7), 1893-1903.

Soil Survey Staff, 1987. Keys to soil taxonomy, Management Support Service. third edition Cornell University, Ithaca, New York.

Ta, T.C., Macdowall, F.D.H., Faris, M.A., 1986. Excretion of nitrogen assimilated from $\mathrm{N}_{2}$ fixed by nodulated roots of alfalfa (Medicago sativa). Can. J. Bot. 64, 20632067.

Temperton, V.M., Mwangi, P.N., Scherer-Lorenzen, M., Schmid, B., Buchmann, N., 2007. Positive interactions between nitrogen-fixing legumes and four different neighbouring species in a biodiversity experiment. Oecologia 151 (2), 190-205.

Turner, G.L., Bergersen, F.J., 1983. Natural abundance of ${ }^{15} \mathrm{~N}$ in root nodules of soybean, lupin, subterranean clover and lucerne. Soil Biol. Biochem. 15 (5), 525 530 .
Vallis, I., Haydock, K.P., Ross, P.J., Henzell, E.F., 1967. Isotopic studies on the uptake of nitrogen by pasture plants. III. The uptake of small additions of ${ }^{15} \mathrm{~N}$-labelled fertilizer by Rhodes grass Townsville lucerne. Aust. J. Agric. Res. 18, 865-8877.

Vitousek, P.M. Howarth, R.W., 1991. Nitrogen limitation on land and in the sea: how can it occur? Biogeochemistry 13 (2), 87-115.

Xiong, X.G., Han, X.G., 2006. Resoruces islands and its roles in the thicketization of grasslands and thicketization grasslands. Acta Prarm. Sin. 15 (1), 9-14.

Xiong, X.G., Han, X.G., Bai, Y.F., Pan, Q.M., 2003. Increased distribution of Caragana microphylla in rangelands and its causes and consequences in Xilin River Basin. Acta Pharm. Sin. 12 (3), 57-62.

Xu, L., Gao, Q., Wang, Y.L., 2014. Species richness within a six-year slope exclosure in a temperate grassland and its relationship with aboveground biomass. Ecol. Environ. Sci. 23 (3), 398-405.

Yan, Z.Q., Qi, Y.C., Dong, Y.S., Peng, Q., Sun, L.J., Jia, J.Q., Cao, C.C., Guo, S.F., He, Y.L., 2014. Nitrogen cycling in grassland ecosystem in response to climate change and human activities. Acta Pharm. Sin. 23 (6), 279-292.

Yang, B.J., Qiao, N., Xu, X.L., Ouyang, H., 2011. Symbiotic nitrogen fixation by legumes in two Chinese grasslands estimated with the ${ }^{15} \mathrm{~N}$ dilution technique. Nutr. Cycl. Agroecosyst. 91 (1), 91-98.

Zhang, L., Wu, D.X., Shi, H.Q., Zhang, C.J., Zhan, X.Y., Zhou, S.X., 2011. Effects of elevated $\mathrm{CO}_{2}$ and $\mathrm{N}$ addition on growth and $\mathrm{N}_{2}$ fixation of a legume subshrub (Caragana microphyllaLam.) in temperate grassland in China. PLoS One 6 (10).

Zhou, D.W., 1990. Caragana microphylla shrub grassland in Inner Mongalia. Inner Mongolian Prat. 03, 17-19. 